\title{
Mai te hau Roma ra te huru: \\ The Illusion of "Autonomy" and the \\ Ongoing Struggle for Decolonization \\ in French Polynesia
}

Lorenz Gonschor

\begin{abstract}
At the Ministerial Meeting of the Coordinating Bureau of the NonAligned Movement (NAM) in Sharm El-Sheikh, Egypt, on 9 May 20I2, the representatives of Papua New Guinea and Fiji introduced a resolution, which was approved and included in the meeting's communiqué, stating that the organization, consisting of I 20 member states, "affirmed the inalienable right of the people of French Polynesia-Ma'ohi Nui to selfdetermination in accordance with Chapter XI of the United Nations and the UN General Assembly Resolution I 5 I 4 (XV)" (Fiji Ministry of Information 20I2). ${ }^{1}$ The same statement was reiterated at the Non-Aligned Movement summit in Tehran, Iran, held 26-3 I August 20I2 (NAM 20I2). Representing two-thirds of the UN member states, in the words of a Fijian journalist reporting on the issue, "The support by the I 20 members of the movement will greatly assist the advancement of the issue in the United Nations" (Pratibha 20I2). After an intensive lobbying campaign throughout the rest of the year, a draft General Assembly resolution was released to the public by the French Polynesia president's office on 3 I January 2013, officially published by the United Nations on 7 February, republished in an amended, streamlined version on I March, and passed by unanimous vote of the General Assembly-with France absent and a few other Western countries declaring their dissent-on I7 May (UN 20I3).

The news from Egypt, Tehran, and New York, while received enthusiastically by French Polynesia's pro-independence President Oscar Temaru and other proponents of Maohi (native Tahitian) nationalism, drew sharp criticism from the pro-French opposition parties. A I 5 May 20 I 2 press
\end{abstract}

The Contemporary Pacific, Volume 25, Number 2, 259-296

(C) 2013 by University of Hawai'i Press 
statement of the Tahoeraa Huiraatira (People's Rally) party of former President Gaston Flosse called the resolution of the Non-Aligned Movement an "inacceptable interference in the internal affairs of France," and in his own press statement the same day, Gaston Tong Sang, another former territorial president, affiliated with the major French right-wing party Union pour un Mouvement Populaire, denied the legitimacy of Fiji's and Papua New Guinea's activism based on their governments' poor democratic performance.

The controversy about the statements at the recent NAM and UN meetings is only the latest episode in a fierce debate about French Polynesia's international status and its right to self-determination as a Non-Self-Governing Territory (NSGT). For the last six decades, the absence of French Polynesia from the United Nations list of NSGTs dating from its unilateral removal by France in 1947 has represented a great anomaly in the Pacific, as virtually all other dependent territories in the Pacific have been listed. On I 8 August 20II, in a historic moment, the Assembly of French Polynesia voted to support the country's reinscription as a NSGT, giving President Temaru for the first time a clear mandate to act toward that goal. Support for Temaru from independent Pacific Island governments in that sense had so far only been lukewarm but has significantly increased since the August 20I I assembly vote. On the other hand, both the French government and the pro-French opposition have constantly fought against Temaru's campaign with a ferocity bordering on hysteria. Typically, in the French colonial or local pro-French discourse, events relating to the territory's changes in political status in the I940s and I950s are represented inaccurately.

For instance, in February 2008, the editor of a news magazine in Tahiti not only denounced President Temaru's efforts to relist French Polynesia as a NSGT as a "paranoid attack against the [French] State" but also claimed in an article in the same issue that the 1956 French loi-cadre ("framework law" for the internal autonomy of French overseas territories) was "abolished in Tahiti through the referendum of 1958. ." 2 As we will see in detail later in this article, it is completely inaccurate to claim that the French constitutional referendum in 1958 caused or justified the abolition of internal autonomy in Tahiti, but this is often done in pro-French discourse in order to obscure what really went on during that time, which was nothing less than an arbitrary reassertion of French colonial authority, shutting down a process of decolonization that had already been initiated.

At the other end of the spectrum, in 1998, popular Tahitian musician 
and songwriter Angelo Ariitai Neuffer, famous for his political protest songs, released an album named Atire Atire (Enough, Enough!), which featured, among many songs denouncing French rule and the local proFrench establishment in high poetic and musical quality, a piece titled "Hau Metua Roma" (Roman Mother Country) with the following lyrics:

E au te hau metua

Mai te hau Roma ra te huru

$\mathrm{O}$ te aneti i te fenua Iseraela

E au te hau metua

Mai te hau Roma ra te huru

O te haavi i te nunaa Iseraela

Noa atu ua pohe Heroda

Area ra tana mau tamarii

Te ora noa ra ratou i teie tau

Noa atu ua pohe Ceisara

Area ra tana mau huaai

Te faatiti noa ra ratou i teie tau

Hau metua Roma

Faahoi mai tau fenua

Faahoi mai tau fenua

Iseraela Maohi e
The mother country

is like the Roman Empire

that annexed the country of Israel

The mother country

is like the Roman Empire

that enslaved the people of Israel

Even though Herod is dead

his children

are still alive today

Even though Caesar is dead

his descendants

continue to enslave people today

Roman mother country

give us back our land

give us back our land

our Maohi Israel ${ }^{3}$

This song-shocking to many pro-French locals and the few French fluent enough in Tahitian to understand it-can be interpreted at many levels. Very apparently, it represents a Christian millenarian vision for the future of the country, with the Maohi people identified as the people of Israela recurrent topic in Tahitian nationalism that has been well researched by Tahiti-based French anthropologist Bruno Saura (I998, 2004) but is beyond the scope of this article. On a simpler level, the song uses an analogy of well-known New Testament history to denounce ongoing French colonialism in Tahiti as well as its local collaborators. Hau metua (parent government), a literal translation of the French terms métropole (from the Greek for "mother city") or mère-patrie (mother country), is easily identifiable as a reference to the French government, and Caesar and Herod might be direct allusions to then French President Jacques Chirac and his close local ally, then French Polynesia President Gaston Flosse, or, alterna- 
tively, to I960s President Charles de Gaulle and certain pro-French Tahitian leaders of that period.

Why would Neuffer say in his song that the French government is "mai te Hau Roma ra te huru" (like the Roman Empire), when many others, Tahitians and French, consider relations between French Polynesia and France to be cordial and the current political situation of the country as an autonomous territory within the French Republic a satisfying arrangement? And why do Oscar Temaru and several other politicians today insist that their country is a French colony in need of decolonization? In this article I argue that despite passionate arguments to the contrary, in French Polynesia, colonialism is not an issue of the past.

I begin by recounting the political history of the country since the second half of the twentieth century, arguing that mutually interconnected acts of colonialism by the French State in the late I950s and I960s constituted acts of virtual recolonization that have traumatized French Polynesian society to this day, continued by a colonial policy of manipulating local politics and arbitrarily changing the rules to support political leaders favorable to French interests.

\section{The Trauma of "Recolonization": Pouvanaa a Oopa and the Centre d’Experimentations du Pacifique}

By the time of World War II, the core islands of the Etablissements Français de l'Océanie (EFO, French Establishments of Oceania), as the territory was then called, had been under French rule for roughly a century. Comprising about $\mathrm{I} 20$ islands in the central eastern Pacific, spread over a vast maritime area comparable in size to central Europe, the territory is made up of six archipelagoes: the Windward Islands (Nia Matai); Leeward Islands (Raro Matai); Austral Islands (Tuhaa Pae); Tuamotu Islands; Gambier Islands (Mangareva); and Marquesas Islands (Henua Enana or Fenua Enata) (see map I). The main island of Tahiti in the Windward Islands, with the capital Papeete, unified as an independent kingdom under the Pomare dynasty since I 8 I 5 , was placed under a forced French protectorate in 1842 and remained so until $\mathrm{I} 880$ when it was formally annexed as a French colony. The various outer islands, some of which had formed their own native kingdoms, were subsequently annexed and incorporated into the EFo between I 880 and I90I.

On most islands, the process of colonization was not at all a smooth affair. Usually, if interested in taking an island, France first tried to obtain 


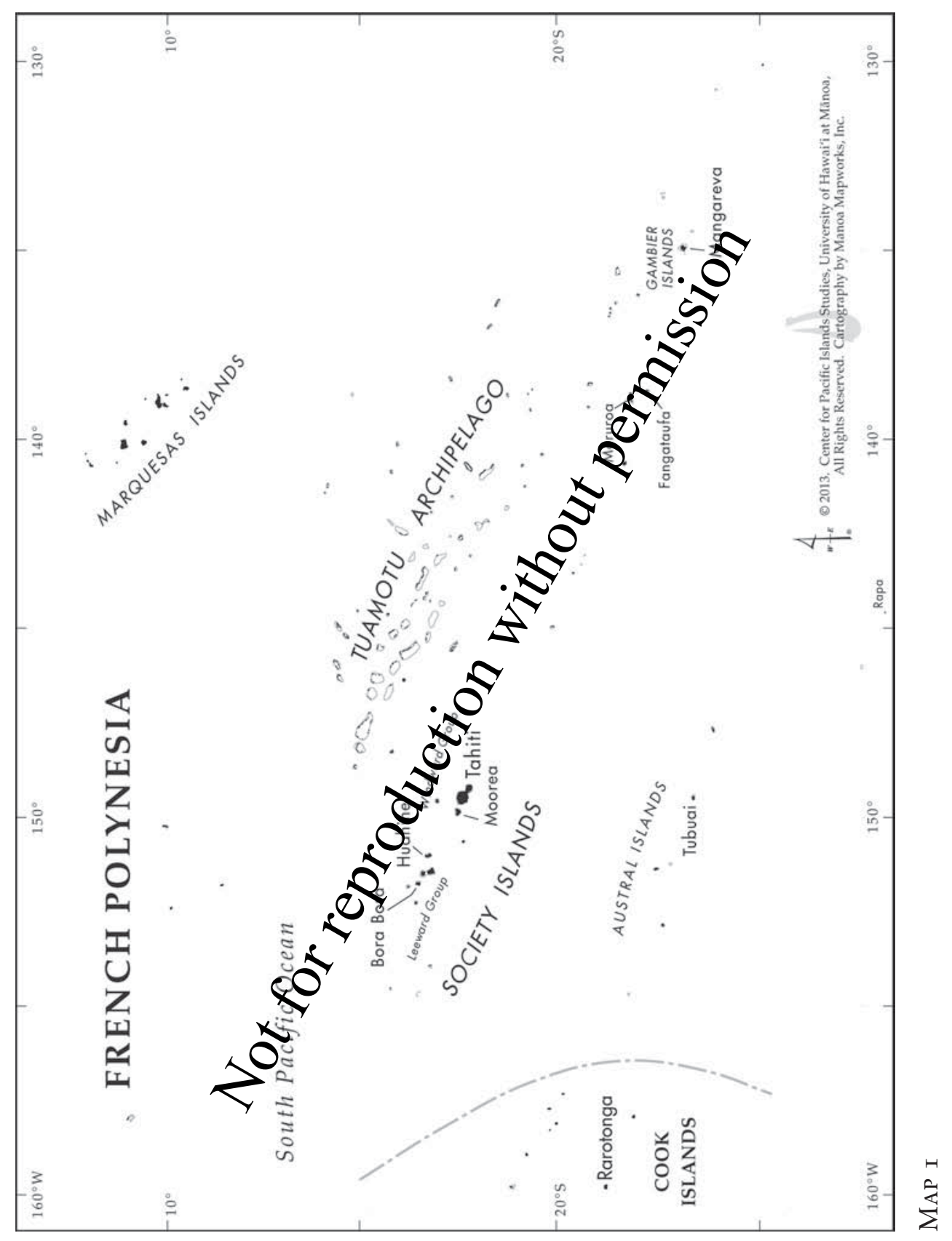


the consent of the native government or tribal leaders for the acquisition of their territory, but the French ultimately enforced their intentions with the threat or use of violence. French historian Pierre-Yves Toullelan wrote in I99I, "[French] Polynesia did not give itself to France but had to be conquered by the force of arms." ${ }^{4}$ In cases where relatively strong native states existed, France's strategy was to first establish a protectorate, then subvert and undermine the local government within that protectorate, and finally get it annexed-if possible by consent, if not by force.

After the submission of the last movements of armed resistance in the Leeward Islands in the late I890s, there was no visible political movement in the EFO for several decades. Some instances of political resistance occurred in the late I920s and early I930s, but the first true twentiethcentury nationalist movement was led by Pouvanaa a Oopa after World War II. Born on Huahine in the Leeward Islands in I895, only a few months before the island submitted to French rule, Pouvanaa fought as a volunteer for the French army in World War I and declared himself in favor of the pro-allied French exile government under General Charles de Gaulle during World War II. At the same time, Pouvanaa protested against injustices of the colonial system and was arrested and jailed several times, which made him quickly popular among the rural and working-class population (Regnault I996, 5 I-53; Saura I997, I I3-I95).

After Paris conferred French citizenship on all native inhabitants of the EFO in 1945 and the status of all French colonies was changed to that of territoires d'outre-mer (overseas territories), the EFO were granted a democratically elected representative assembly for the first time, while the territory also received representation in the French parliament-one member in the National Assembly and one in the Senate. However, executive power remained firmly in the hand of the Paris-appointed governor, who kept all the prerogatives outlined in an I 885 decree (Regnault I996, 36; Gille 2006, 55, 85-87).

This new framework of electoral democracy made it possible for Pouvanaa to organize his growing support into a political party, founded in I947 and called Rassemblement Démocratique des Populations Tahitiennes (RDPT, Democratic Rally of the Tahitian Populations) in 1949. With his popularity steadily increasing through his leadership of further protests against ongoing injustices, Pouvanaa was elected member of the French National Assembly in October 1949. As RDPT was one of the first anticolonial parties in the Pacific, its ideology contained strong socialist and nationalist elements, and throughout the I950s, it dominated the 
political scene in the territory, constantly winning large majorities at all elections (Regnault 1996; Dorrance 1966, 82-83; Tagupa 1976, 5-8).

With similar movements dominating the assemblies of most of its territories, France eventually gave in to some of their demands and in 1956 enacted the so-called loi-cadre (framework law), which provided a framework for limited self-government in all overseas territories. ${ }^{5}$ For the first time, executive power was partially exercised by an elected body, as under the new statute, the assembly elected a government council, composed of six to eight ministers, which was presided over by the governor but had an elected vice president who acted as a sort of chief minister. Key aspects of sovereignty such as foreign affairs, internal security, and justice remained the exclusive responsibility of the governor, but most local service agencies were placed under the territorial government, each headed by one of the ministers. The assembly received quasi-legislative powers in these areas. Unsurprisingly, Pouvanaa was elected to the post of vice president in December 1957. While leading the territorial government, members of his party contemplated the formation of a "Tahitian Republic" within the French Union as the next step in the process of decolonization. However, local business interests vigorously opposed the new government's policy for more social equality, which led to increasing political and social tensions during 1958 and eventually to a split of the governing party between Pouvanaa and his lieutenant, Jean-Baptiste Heitarauri Céran-Jérusalémy (Gille 2006, 88-92; Regnault I996; see Céran-Jérusalémy 200I for an autobiographical account).

In mid-I958, however, there were drastic changes in France, as General Charles de Gaulle rose to power and a new constitution was drafted for the Fifth Republic. The new framework for the republic's overseas possessions became the Communauté Française (French Community), consisting of metropolitan France, the overseas territories, and autonomous member states associated with France (Government of France 1958, section XII, article 77-87). A national referendum on the constitution was held on 28 September 1958 and included all overseas territories. Pouvanaa campaigned for a "no" vote, which was understood to lead to immediate independence, whereas Céran-Jérusalémy joined the business establishment in their campaign for "yes." The French administration aided the proponents of "yes" and hindered the campaign of Pouvanaa, who was denied access to radio and to transportation to outer islands. Some of his campaign activists were detained without charges. Under these conditions, the "yes" campaign was unsurprisingly successful in French Polynesia, but neverthe- 
less the proportion of "yes" votes at 64.42 percent was rather moderate. In most other French territories, over 90 percent voted "yes" (Dorrance I966, 46-48; Toullelan and Gille I994, I42; Regnault I996, I74-I83).

Shortly after the referendum, tensions between pro- and anti-French Tahitians rose, and some acts of violence took place. On 8 October, the governor suspended the government council, and on I I October, Pouvanaa was arrested, in spite of his parliamentary immunity as a National Assembly member. He was later sentenced to eight years of imprisonment and fifteen years of banishment in France for complicity in attempted arson. In a speech, he had quoted the Bible about the destruction and reconstruction of the temple of Jerusalem, which was construed as a call to burn down Papeete (Saura 1997, 35 I-352). Contemporary observers generally assumed that the trial was a farce (Ilari 1965, 30I; Dorrance I966, 52-53) same time, a local pro-French politician who had distributed a pamphlet calling very unambiguously for physical violence against Pouvanaa was not even charged. ${ }^{7}$

After Pouvanaa's arrest, under pressure and in fear, the assembly voted to dismiss the government council, which was implemented by decree in October 1958 . According to article 16 of the 1958 constitution, the assembly of each overseas territory that had voted "yes" in the referendum had to choose between three options: retain the status quo, go for départementalisation (ie, become an administrative division of metropolitan France), or become a member state in the Communauté. While most overseas territories chose the third option, the assembly of French Polynesia voted on I 4 November 1958 to remain an overseas territory. It also voted to strip the local government council of most of its powers. In an executive order of 23 December 1958, the institutions of the loi-cadre were virtually abolished. Under the new statute, the government council was presided over by the governor or his secretary, and its members, proportionally elected by the assembly, no longer had ministerial responsibilities. In fact, the governor became once more the all-powerful head of the territorial administration, and the incipient process of devolution was virtually terminated (Dorrance I966, 55; Regnault I996, I86-I88).

When leading members of Pouvanaa's party later attempted to revise the decision of the assembly of November 1958 and obtain a status of associated state in the Communaute for the territory in 1963, this was refused, and both factions of the RDPT were "dissolved"-that is, banned-by executive decree in 1963 for advocating the dismemberment of the "terri- 
torial integrity" of France (Dorrance 1966, 70-72; Tagupa 1976, I6; Regnault I996, I92-I94). Apparently the territory was now suddenly seen as an integral part of France, even though the constitution, in article 74-76, did not clearly and unambiguously define overseas territories as such.

The reason for this anachronistic tightening of colonial authority during an era of global decolonization became clear a few years later when in I96I-62 the French government under President de Gaulle decided to establish in the territory a nuclear weapons testing center, the Centre d'Experimentations du Pacifique, which was officially announced in early 1963. Despite the resistance of some leading local politicians, the program was implemented, and the first test was conducted on the atoll of Moruroa in the Tuamotu Archipelago in 1966. ${ }^{8}$ For the following decades, the political and economic life of French Polynesia was dominated by the French military, and any moves toward local self-government were suppressed. Not only did the tests cause irradiation, but the militarization of the territory also led to a massive social and economic upheaval through the influx of great numbers of military and civilian personnel and massive amounts of money (Danielsson and Danielsson I986, I993).

Tahiti-based French historian Jean-Marc Regnault has found ample evidence that the conviction and banishment of Pouvanaa was indeed a scheme of the French government because of the territory's strategic importance (Regnault 2003 a, 77-I36; 2003 b). ${ }^{9}$ For instance, then French Minister of Justice Edmond Michelet complained to the minister of overseas territories about the irregularities in the arrest and trial of Pouvanaa, including the fact that the judicial docket file for the case was empty, but his complaint was never followed up, apparently for reasons of "national interest" (Regnault 20IIa). For the same reason, pressure was put on the territorial assembly to vote to maintain overseas territory status and get rid of the loi-cadre institutions (Regnault I996, 20I-204). In a telegram on 15 September 1958, a few days before the referendum, the French minister of overseas territories advised the governor of French Polynesia, "It should be well understood that French Polynesia must ask for the status of overseas territory and not for that of member of the Community." ${ }^{10}$ From the point of view of the French government, it was thus never contemplated that the territory should freely determine its own status, not even within the framework of the Communauté Française, but merely that its voters and its assembly give a façade of democracy to a decision already made in Paris.

The disastrous long-term impacts of three decades of nuclear testing (46 
atmospheric explosions between I966 and I973 and I47 underground explosions between 1974 and 1996) on the environment, health, and economy of the territory, the details of which are beyond the purview of this article, have been well documented in various independent studies (Danielsson and Danielsson 1986, I993; de Vries and Seur 1997; Barillot 2002) and most recently by a special inquiry committee of the French Polynesia assembly (APF 2006). However, so far, the French government has not officially admitted to having caused these impacts, let alone apologized for them. Until 2006, the French government policy was to claim that the nuclear tests were entirely "safe," and while in 20 Io the French parliament enacted a law that in principle enables victims of irradiation to make claims for compensation, the law in its current version has too many flaws to make it effective, as I have described elsewhere (Gonschor 20I0, I76-I77; 20II, 22I; 20I2, I8I; see also Al Wardi and Regnault 2OII, I03-IO5).

French government responses to the injustice of the Pouvanaa sham trial have been largely similar to those to nuclear testing-namely, turning a deaf ear on the affair. After the assembly of French Polynesia repeatedly voted to demand a retrial, and Richard Ariihau Tuheiava, currently one of the two senators representing French Polynesia in the French senate, had reiterated these demands (Regnault 20Iгa), a review of the trial was initiated in April 20I3. The very fact that the affair has to be treated like a regular criminal trial, rather than simply declared a politically motivated show trial and therefore null and void (as other abusive judicial decisions of authoritarian regimes have been), attests either to an obvious will to conceal the arbitrary nature of colonial justice or to great naiveté about it.

But the continuing denial of colonial history and the outright mockery of its victims by the French government also manifests itself on the symbolic level. On 28 June 2006, President Temaru's cabinet decided to rename the main street in the administrative district of Papeete "Aroa Nui Pouvanaa a Oopa" (Pouvanaa a Oopa Avenue). Previously, it had been known as Bruat Avenue, after Armand-Joseph Bruat, the first French colonial governor in the $\mathrm{I} 840 \mathrm{O}$. A few days later, Temaru inaugurated a monument to the victims of French nuclear testing in a beachfront park to mark the fortieth anniversary of the first nuclear test on Moruroa. Instead of supporting these symbolic acts as a gesture of reconciliation, French High Commissioner Anne Boquet denounced both the monument and the street renaming as "unfriendly gestures" toward France, implying that only continuing to ostracize Pouvanaa's memory and denying the damages caused 
by nuclear testing would be "friendly" policies (TP, $3 \circ$ June, 2 July, 3 July 2006). ${ }^{11}$

\section{Anomalies of Decolonization, International AND Domestic}

The arrest and imprisonment of Pouvanaa, the abolition of loi-cadre selfgovernment, and the imposition of the Centre d'Experimentations du Pacifique in French Polynesia were not simply arbitrary acts of an authoritarian colonial government. What makes them so troublesome is that they happened during a time when Western colonies were achieving independence in Asia and Africa; even in the neighboring insular Pacific territories, the process of decolonization was beginning to unfold, with Western Samoa becoming the first to gain independence in I962 (Naidu I993, I 29-I30). ${ }^{12}$ From a more legalistic point of view, the policy pursued in French Polynesia also represents a great anomaly in terms of the decolonization process institutionalized by the United Nations, as well as in terms of the French domestic decolonization process.

Before returning to the specific case of the EFo/French Polynesia, let us briefly recall the history of the UN decolonization regime. The Charter of the United Nations, enacted in June 1945, contains in chapter XI a "declaration regarding non-self-governing territories," which stipulates that members in possession of "territories whose people have not yet attained a full measure of self-government" should recognize the interests of their people as paramount. The administering powers were furthermore instructed to develop self-government; to promote economic, social, and educational advancement in these territories; and, in article $73 \mathrm{e}$, to transmit regularly information on the progress of these developments to the secretary-general of the United Nations. Sovereignty of colonial powers over their colonial territories was thus for the first time limited (Ahmad I974, 9-IO, 372-374). However, the wording was still weak and ambiguous, mentioning only "self-government" and not necessarily independence as the goal of the political evolution of the territories. One year later, the UN General Assembly passed resolution 66 (I) of December 1946, laying a foundation for dealings with the territories referred to in chapter XI of the charter. The resolution established a list of seventy-four territories about which information was to be transmitted by the administrative powers according to article $73 \mathrm{e}$, as well as a committee to collect that information (UN I946). 
However, the defining characteristics of NSGTS remained ambiguous and became an issue of contention among $\mathrm{UN}$ member states. In reaction, the General Assembly passed several resolutions throughout the I940s and I950s to define NSGTS and the responsibilities of administering powers more clearly (Ahmad I974, I70, I83, I88-263, 283-286, 390). The systematization of the legal framework for decolonization culminated in 1960. After a large number of former dependent territories in Africa had become independent countries and joined the United Nations, the General Assembly became predominantly anticolonial and subsequently passed the "Declaration on the granting of independence to colonial countries and peoples" as resolution I5I4 (XV) in December of I960. This declaration clearly and unambiguously called for the decolonization of the remaining NSGTS, stating:

I. The subjection of peoples to alien subjugation, domination and exploitation constitutes a denial of fundamental human rights, is contrary to the Charter of the United Nations and is an impediment to the promotion of world peace and cooperation.

2. All peoples have the right to self-determination; by virtue of that right, they freely determine their political status and freely pursue their economic social and political development.

3. Inadequacy of political, economic, social or educational preparedness should never serve as a pretext for delaying independence. (UN I960a, article I-3)

To complement these powerful words with practical definitions, the UN General Assembly passed resolution I 54I (XV), which defined more clearly than ever before the criteria for a territory to be listed as non-selfgoverning, as well as the conditions for such a territory to be regarded as decolonized. A full measure of self-government can be reached in three ways, after which there is no longer an obligation to transmit information: “(a) Emergence as a sovereign independent State; (b) Free association with an independent State; or (c) Integration with an independent State" (UN I96ob).

Following World War II, France promised in the preamble to its I946 constitution to grant its colonies self-government. In wording that clearly reflected article 73 of the UN charter, the preamble stated:

Faithful to its traditional mission, France intends to conduct the peoples of which she has taken care to the liberty of governing themselves and manag- 
ing democratically their own affairs; ruling out any system of colonization founded on arbitrariness, she guarantees to all equal access to public functions and individual or collective exercise of rights and liberties hereafter proclaimed or confirmed. (Government of France I946) ${ }^{13}$

Following these ideals in its constitution, France listed almost all of its overseas possessions as NSGTS. The EFO thus figured on the 1946 list among those territories about which France transmitted information to the United Nations (UN 1946). However, only one year later, in I947, France stopped transmitting information on the territory, effectively removing it from the list, together with New Caledonia, Saint-Pierre and Miquelon, and the French Establishments of India, ${ }^{\mathrm{I}}{ }^{4}$ while information continued to be transmitted on the other French territories. Initially, no official explanation was given for this selective removal (Ahmad I974, I 83). In a 1949 statement, France declared the definition of NSGTs to be a matter of exclusive national competence, despite the passage of a UN resolution stating the contrary (El-Ayouty I97I, I 52; Ahmad I974, I79, I 87, I90). One year earlier, in I948, but still a year after the unilateral removal, the granting of "extensive political rights" and a regime "closely resembling ... that of Metropolitan France" had been given as a justification for the removal of the EFO (UN General Assembly report, third session, quoted in Ahmad 1974, I90-19I). The first explanation might refer to the granting of French citizenship to all inhabitants of the EFO in I945, whereas the second is not very convincing at all, as the political organization in the EFO after I945, as described above, remained vastly different from and certainly less democratic than that of metropolitan France (Regnault 2006, 55 ).

The removal of both the French Establishments in Oceania and New Caledonia from the list in 1947 was thus clearly arbitrary. For New Caledonia, this unjust situation was eventually corrected through a reinscription process in 1986 (UN I986), but the French Polynesia case remained unresolved until 20I3. ${ }^{15}$ After removing it from the list, France attempted to minimize the international engagement of the territory. This was shown very bluntly in Fiji in I950 at the first South Pacific Conference, a meeting organized by the colonial powers to promote the development of Pacific Island territories, in which most of the leading native politicians of the Pacific participated. At this conference, French Oceania was the only territory represented not by an Islander but by a European (Fry I997, I 86). This appears totally illogical, especially as the territory was by then one 
of the most politically developed in the Pacific, and National Assembly Member Pouvanaa a Oopa or another RDPT leader would have been its obvious representative. It thus seems likely that France deliberately tried to keep local politicians unaware of political developments in the region.

Even though United Nations involvement with the EFO ended with the withdrawal from the list in 1947 , decolonization efforts continued both within the territory and in the larger French system. In the referendum on the new French constitution in September 1958, a large majority in all overseas territories voted "yes," except for Guinea, which voted "no," resulting in immediate independence. ${ }^{16}$ Most other territories then voted to become member states of the French Community, a type of freely associated status. Two years later the French Community was dissolved and all its member states became fully independent by mutual consent in 1960 (Yacono I97I, 9I-IOI). Looking back at the 1958 events in Tahiti, the position of Céran-Jérusalémy, advocating a Tahitian republic but voting "yes" in the referendum, was probably a more reasonable strategy for the eventual achievement of independence than Pouvanaa's campaign for a "no" vote, in other words advocating an immediate break-off independence like Guinea (Henningham I992, I24). The assertion that the 1958 "yes" vote was a vote against independence and for remaining a French territory forever, as has been repeatedly claimed by the French government (Tagupa 1976, I9; Danielsson and Danielsson I986, I19), is thus fundamentally wrong. In fact, voting "yes" meant only the rejection of immediate independence and the willingness to cooperate with France in a continuing decolonization process. Had France not arbitrarily intervened in the aftermath of the referendum, French Polynesia would likely have followed the model of the African territories in becoming a member state of the French Community and achieving independence in 1960 (Regnault 2OIIC).

But the list of chances for decolonization goes on. Besides French Polynesia, there were only three other territories with native populations whose assemblies voted to retain overseas territory status after the 1958 referendum, namely New Caledonia, the Comoro Islands, and French Somaliland (now known as Djibouti) (Yacono I97I, 9I). Strangely enough, of these four, three retained the loi-cadre institutions of an elected council of ministers and a vice president, whereas in French Polynesia these institutions were removed and an authoritarian governor-centered administrative system of pre-loi-cadre times restored. Eventually a similar curtailing happened in New Caledonia in I963 (Lenormand I991, I43; 
Regnault 2003a, I35), but the other two territories, the Comoros and French Somaliland, retained their vice presidents and local governments. As independence movements were on the rise in the latter two territories, both eventually received a status of internal autonomy, and under pressure from the neighboring newly independent African states, both territories were later also reinscribed on the UN list of NSGTS (UN I966, I973); they eventually achieved independence in 1975 and 1977 , respectively. ${ }^{17}$ During the same time, French Polynesia and New Caledonia remained under an authoritarian system of government without any locally elected chief executive.

With this calculated denial of self-determination, both French Pacific territories thus clearly represent anomalies, not only under international law but also within the larger picture of French domestic decolonization. ${ }^{18}$ In French Polynesia's case, that denial from 1958 onward could be readily understood as motivated by military considerations concerning the planned nuclear testing center (Regnault I996, 197-204; 2003a, II9-I 35; 2006, 2I7). However, it is not entirely clear why this systematic denial of decolonization and arbitrary distinction from other territories dates back to 1947, a time when France had no major military installations there. The most likely explanation is that France planned from very early on that in case it had to grant most of its territories independence, it would keep some small insular remnants of its empire-which allowed, at a comparatively low cost overall, the maintaining of a worldwide chain of military bases, and thus enabled France to remain a global power. ${ }^{19}$

\section{The Concept of Autonomy: Merits and Excesses}

Despite the repression and dismantling of local self-government in I958-1963 as related earlier, French Polynesia today ostensibly enjoys once more a great degree of self-government under a system of so-called "autonomy," which was recently brought forward by French Minister of Overseas Territories Marie-Luce Penchard as an argument for why reinscription as a NSGT was not necessary (TP, I9 Aug 20II). An assessment of the validity of that argument thus warrants a closer examination of the particular status of autonomy and its history in French Polynesia. As international law scholar Maivân Lâm defined it, "Autonomy" can be defined as a "political term to designate domestic devolutions of power to substate groups" (2000, I40), thus representing a progressive step within a decolonization process, empowering the local population in its relation with 
the ruling power, and furthering the development of political leadership. Autonomy is therefore a good first step in the process of decolonization. In Where Nation-States Come From, American political scientist Philip Roeder pointed to the role of segment-states-that is, autonomous statelike entities within sovereign states-as the core institutions on which new nation-states can be built, the independence of which should above all be understood as an "administrative upgrade of an existing jurisdiction" $(2007$, IO). Looking at the recent history of the region, one notes that all Pacific Island territories that later became independent went through a preparatory period of territorial autonomy for several years before achieving independence, each of them a good case to confirm Roeder's "segment-state" thesis. ${ }^{20}$

Among the French overseas territories, the concept of autonomy was first applied through the enactment of a statute of internal autonomy for the Comoros Islands in I96I, later followed by a similar statute for the Djibouti territory (then called the French Afar and Issa Territory) in I967. Both territories were governed under this system, with a territorial government headed by an indirectly elected president, until their independence (Tagupa 1976, I9; Ibrahime 2000, 8I-82; Thompson and Adloff I968, 99-IOI).

While the Comoros and Djibouti enjoyed these autonomy statutes, and eventually achieved independence, the French Pacific territories were run by an authoritarian governor and had virtually no autonomy at all, since even the loi-cadre institutions had for the most part been abolished, as explained earlier. This inconsistent and unjust situation was strongly denounced by the leading politicians of the two Pacific territories throughout the late I960s and early I970s, but to no avail in Paris. Throughout the I970s, an increasingly assertive autonomist movement under National Assembly Member Francis Ariioehau Sanford, then a follower of Pouvanaa, continued its efforts to obtain internal autonomy, which Sanford described as a way of "decolonizing without ceasing to be French" (Haupert I998, I8), though he also threatened to turn toward independence if no autonomy was given and underlined the campaign with acts of civil disobedience (Tagupa I976, I 8-2I).

Under this enormous popular pressure, the French government eventually gave in, and in July 1977 it reorganized the political institutions of the territory, creating a system similar to the loi-cadre institutions of I957-58, commonly referred to as autonomie de gestion (autonomy of management), with a territorial government council led by an elected 
vice president, a position first taken by Francis Sanford, then from 1982 by his pro-French opponent Gaston Flosse. The territorial government became responsible for all fields of governance not specifically attributed to the French State, which, however, were still many, including not only defense and foreign affairs but also many internal affairs. The governor was renamed high commissioner and the decree of I 885 that defined the nearly absolute powers of his position was finally abolished, although he remained the formal head of the territorial administration (Gille 2006, 96-IOI).

Administrative reforms undertaken in 1982 by Socialist French President Mitterrand in metropolitan France set the stage for further devolution of the territory's powers in September 1984 under a statute of "internal autonomy," essentially similar in extent to the former statutes of the Comoros and Djibouti. The French State and the territorial administrations became fully separated, the former being headed by the high commissioner, the latter by a president elected by the assembly. Additionally, the territory was allowed to adopt its own state-like symbols (flag, coat of arms, and anthem), and its prerogatives were further extended, including participation in foreign affairs if they concerned neighboring Pacific Island countries (Gille 2006, I02-I I4).

In August I995, the French constitution was revised, deleting the provision in article I referring to the "peoples of the Overseas Territories" and all articles referring to member states of the French Community (which had de facto ceased to exist in 1960) (Government of France 1995). While the overall position of overseas territories was thus significantly weakened, in April 1996, after the definitive closure of the nuclear testing center, a new statute for French Polynesia was passed, once more increasing the responsibilities of the territorial government. While President Flosse soon demanded another revision to achieve even more power for the territory, the local opposition began criticizing the concept of increased autonomy as a cover for authoritarian rule by Flosse. ${ }^{21}$ Indeed, as Tahiti-based political scientist Sémir Al Wardi described in the aptly titled 2008 book Tahiti Nui ou les dérives de l'autonomie (Tahiti Nui or the Excesses of Autonomy), during the I990s and early 2000s, with the blessing of the French government, Gaston Flosse was able to construct a sort of authoritarian patronage regime not unlike those in many independent postcolonial states and use the concept of autonomy to shield this regime from the scrutiny of French legal and political standards (Al Wardi 2008, I09-I6I).

In March 2003, with Gaston Flosse at the peak of his power and his 
supporters enjoying a great majority at the national level, the French government undertook another major revision of its constitution with regard to overseas possessions. The category of territoire d'outre-mer (overseas territory) was abolished, replaced by that of collectivité d'outre-mer (overseas collectivity), each of which would be governed by a proper organic law reflecting its local specificities, with a considerably extended range of possible powers to be devolved to them (Government of France 2003).

Following that enlarged constitutional framework, a new organic law for French Polynesia was elaborated and passed in February 2004 (Government of France 2004). The former overseas territory was now defined as a pays d'outre-mer (overseas country), and its prerogatives became once more substantially extended. Besides an increase of responsibilities in administrative matters, French Polynesia now can, if permitted by the French government, enter into its own relations with foreign governments and establish representations there. The territory can also become a member or observer of international organizations-which it subsequently did when it became first an observer and then an associate member of the Pacific Islands Forum in 2004 and 2006, respectively. Locally, the powers of the assembly were significantly increased, as it can now enact so-called lois $d u$ pays (laws of the country) in certain domains, which have standing almost equal but still inferior to French national laws. Previously the assembly could only enact déliberations (resolutions) without formal legal standing.

While the 2004 statute was lauded by its proponents as the ultimate extension of local self-government within French sovereignty, the local opposition saw it as further empowerment for authoritarian rule by Flosse, blessed by his supporters in Paris, especially since the electoral system was modified to include a majority bonus system so that the leading political party would receive an overwhelming majority in the assembly. ${ }^{22}$ This view was ultimately supported by a large part of the population, and Flosse's party lost power in the first election under the new statute and was succeeded by hitherto opposition leader Oscar Temaru. Temaru's party, Tavini Huiraarira No Te Ao Maohi (Serving the People of the Maohi World), was founded in 1977 as one of many splinter groups demanding outright independence (in contrast to the moderate pro-autonomy nationalists like Sanford), but over the course of three decades, Temaru had succeeded in virtually monopolizing the pro-independence vote and his party had become the leading force in opposition to Flosse (Regnault 2004, 67-76). Due partly to corruption and opportunist patterns of behavior of many 
assembly members (including many of Temaru's followers as well), but also due to major interventions by the French government described later in this article, great instability has followed and majorities have changed frequently since the 2004 election, with Temaru, Flosse, and former Flosse ally Gaston Tong Sang repeatedly winning the presidency and then losing it through no-confidence motions. ${ }^{23}$

Having proven unable to create political stability, the pays d'outre-mer statute has also not guaranteed real local self-government. Despite all the powers granted to the local government, France remains able to make arbitrary modifications to the territory's political system, even against the explicit will of the local assembly. This was exemplified in the fall of 2007 , when a revision of the 2004 statute, including another reform of the election system and a tightening of French government controls over the exercise of power by the local institutions (Government of France 2007), was rushed through the French parliament and passed, despite the fact that a two-thirds majority of the assembly of French Polynesia had previously voted against that modification (TP, 4 Oct 2007).

In contrast, the current political status of New Caledonia provides an example of genuine autonomy within the French system. It is based on the 1998 Noumea Accord between the Kanak Independence movement, pro-French settlers, and the French government, which recognizes the ramifications of colonialism in its preamble and provides for a period of increased autonomy for twenty years before a referendum in which the people will decide whether to remain an autonomous territory under French sovereignty or to become independent. ${ }^{24}$ In order to implement the accord, the French constitution was amended with a specific article on New Caledonia. The autonomy thereby granted to New Caledonia is far more secure than even the 2004 version of autonomy for French Polynesia. Whereas the latter represents a simple organic law enacted through parliamentary vote by metropolitan authorities, the former was enacted in reflection of an accord signed after trilateral negotiations. Furthermore, the constitutional amendment allows New Caledonia to have its own citizenship, restricted to inhabitants of a certain length of residence, so that a further dilution of the local population through French immigration is blocked. In addition, the New Caledonia statute provides for an executive government composed proportionally of all major parties represented in the legislative body, thus avoiding political instability due to unclear majorities. ${ }^{25}$ It also decentralizes power within New Caledonia by dividing the territory into three autonomous provinces-another 
contrast with French Polynesia, the government of which is completely centralized in Papeete, despite significant differences between the five archipelagoes, both ethnolinguistically and in their political history and attitudes toward France. Finally, any transfer of responsibilities from the French state to New Caledonia is by definition irreversible, which makes arbitrary modifications, such as that of December 2007 for French Polynesia, impossible. ${ }^{26}$

Interestingly enough, the Noumea Accord was enacted several years after New Caledonia's reinscription as a NSGT, and one should wonder whether the accord would ever have come into being if the territory had not been under the watch of the United Nations. Minister Penchard's argument that French Polynesia's statute of autonomy makes reinscription unnecessary is thus rather illogical, inverting causes and effects. Rather than being used as a reason for removal from the list, autonomy is usually granted to listed NSGTS as part of a self-determination process. Virtually all NSGTs that are still on the UN list today enjoy a degree of territorial autonomy, some of them as high as or even higher than that of French Polynesia, but in none of them has that granting of autonomy been recognized as a reason for delisting. ${ }^{27}$

Autonomy can thus only be a transition toward, not an alternative to, decolonization. There is no doubt that the statutes of autonomy have had a far-reaching effect on the political scene of the territory, as all politicians in French Polynesia now accept autonomy (some seeing it as an end goal, others as a step toward independence) and reclaim the political heritage of Pouvanaa, while there are no longer supporters of direct colonial rule (Saura 1997, 44I). However, despite the existence of even the most far-reaching statute of autonomy, sovereignty-that is, the "authority to allocate and reallocate all decision rights within [the territory's] borders" (Roeder 2007, 63) -remains with the French government, which has constantly meddled in the territory's affairs, even those purportedly relinquished to local control.

\section{"Unfinished Electoral Processes" and "Red Lines": Colonial Interference Continues}

The unilateral revision of French Polynesia's organic law by the French parliament in 2007 was only one of the latest instances of interference by the French government into the local political process. Throughout his rule, Gaston Flosse and his supporters were virtually free to do as they 
pleased, even if their actions violated applicable French law (Al Wardi 2008, I67-I69, I8I-I82). At the same time, pro-independence and antinuclear activists were subject to monitoring, harassment, and sometimes severe mistreatment by French security agencies. ${ }^{28}$ When Oscar Temaru's coalition won the 2004 elections but held only a precarious majority, the French government started a vigorous campaign to obstruct the formation of a new government under Temaru and to bring Flosse back into power. When the results were announced, Flosse himself admitted to his defeat and suggested that "logically, Oscar Temaru should take my place." ${ }^{29}$ But a few hours later French Minister of Overseas Territories Brigitte Girardin stated in the National Assembly that "the electoral process [was] far from over," 30 causing widespread consternation and insecurity among Temaru and his supporters. Girardin personally made a telephone call to Philip Schyle, leader of a minor party then negotiating a coalition agreement with Temaru, urging him to enter in a coalition agreement with Flosse instead (Al Wardi 2008, I72). Throughout the rest of 2004, the French government, through Minister Girardin and High Commissioner Michel Matthieu, put in place a vast scheme to undermine the Temaru government and put Flosse back in power. These efforts finally succeeded in November 2004 despite unprecedented protests by tens of thousands and continued even after Temaru regained his majority in a by-election in early $2005 .{ }^{31}$ Fittingly, Regnault spoke of "colonial practices in favor of a clan" (2004, I2I).32

While the personal friendship between Jacques Chirac and Gaston Flosse might be seen as a specific reason for the efforts taken by Chirac's government to keep his friend in power, a similar policy of colonial intervention continued under Chirac's successor Nicolas Sarkozy, in office from 2007 to 2012 . Under Sarkozy's presidency, the local political scene underwent a dramatic reconfiguration. Following a major disagreement between Gaston Flosse and his former lieutenant, Gaston Tong Sang, the latter left the Tahoeraa Huiraatira to form his own party, while Flosse, no longer favored by Paris, made a I 80 -degree turn and entered a political alliance with his former archenemy, Temaru. In a July 2007 memorandum of agreement, Flosse and Temaru agreed to respect their diverging political convictions while working together in the interest of the country, intending to develop something akin to the New Caledonian model ( $D T$, 20 July 2007; NT, 2I July 2007). Flosse's subsequent embrace of anticolonial nationalism went so far as to publicly denounce France for its nuclear tests (Flosse 2009) and to lay a wreath for fallen Tahitian 
soldiers who had fought against French colonization in the I 800 S (TP, 30 June 2008).

Confronted with the prospect of a possibly stable broad majority hostile to French colonial interests, Sarkozy's secretary of state (downgraded from a minister) for overseas territories, Christian Estrosi, departed on another campaign of massive interference in the local political process, now with the goal to boost Tong Sang as Paris's new man in Papeete. In the words of Sémir Al Wardi and Jean-Marc Regnault (20II, II 8), "There has been no change [in attitude toward Tahiti] under Sarkozy, who simply replaced Flosse with Tong Sang." As noted earlier, Estrosi, quickly nicknamed "Escrocsi" by some of his Tahitian critics as a wordplay on the term escroc (fraudster), rushed the controversial 2007 organic law reform for French Polynesia through the French parliament, a measure representing only a minority view (Tong Sang's group) and explicitly opposed by a two-thirds majority (representing the Temaru-Flosse alliance) of the Assembly of French Polynesia.

During the campaign for the early elections of 2008 called for in the law, and more so between the two rounds of voting, Estrosi intervened even more directly into local politics. Immediately after the first election round, Estrosi, in the notorious "Girardin-style" described earlier, telephoned Flosse as well as the leader of a minor party, Nicole Bouteau, and advised them to merge with Tong Sang's ticket for the second ballot (TPM, Feb 2008). When Tong Sang's party surprisingly won a relative majority of seats in the assembly, the leadership of Sarkozy's Union pour un Mouvement Populaire (UMP) party congratulated Estrosi for the "successful carrying out of the election," reinforcing the impression that he had interfered in the election process in Tong Sang's favor. During the postelection negotiations, Estrosi once more attempted to interfere in the election process by calling on Flosse to become Tong Sang's junior coalition partner (DT, I I Feb 2008). When these schemes failed and Flosse was elected president with Temaru as his junior partner, Sarkozy remained silent, and Estrosi refused to congratulate Flosse, merely "taking notice" of his presidency ( $T P, 24$ Feb 2008). In stark contrast, when two months later Flosse was overthrown and replaced by Tong Sang in a no-confidence motion after a few representatives had crossed the floor, President Sarkozy and other French government officials congratulated the new Polynesian president immediately after his election (TPM, May 2008). A spokesperson for the UMP party, of which Flosse has been a member for decades, announced the breaking off of all official contacts with Tahoeraa, which used to be 
the UMP's local affiliate, accusing Flosse of betraying the ideals of the UMP by forming an alliance "against nature" with Temaru (TP, 24 Feb 2008). On the other hand, Tong Sang was neither reprimanded nor ostracized from the UMP when he temporarily allied himself with Temaru in April 2009 (TPM, May 2009). Thus it appears that his alliance with Temaru was done on orders from Paris as part of another scheme to destroy the Temaru-Flosse alliance.

In early 20I0, Sarkozy himself revealed his colonialist attitude by declaring (during a speech on principles of French overseas territories policy given on Réunion Island in the Indian Ocean) that independence was an "impassable red line" for French overseas possessions. The statement caused great concern among pro-independence leaders, since it not only attested to a worrisome authoritarian attitude on the part of the president but also clearly contradicted the right of overseas territories to self-determination anchored in the preamble and article 53 of the French constitution (Government of France I958; Al Wardi and Regnault 20I I, 78-79).

\section{Conclusion: The Just Cause of Self-Determination UNDER UN OVERSIGHT}

An assessment of French policy in French Polynesia during the last halfcentury is rather disheartening. In the I940s, I950s, and I960s, the French government arbitrarily pulled the territory out of any available international or French domestic decolonization processes, subjecting it to an anachronistic restoration of colonial authority that included the arrest, sham trial, and long-term imprisonment of its major political leader and other unusually undemocratic measures. All this was done mainly in order to provide France with a location for nuclear weapons testing, which had tremendous environmental, health, and economic consequences during the following three decades. Worst of all, however, France to this day refuses to take responsibility for these acts of injustice and seek reconciliation with the people who were traumatized by them. Misusing the concept of autonomy in order to cover up a de facto continuity of colonial rule and, worse, to create a corrupt authoritarian government favorable to French interests during the I990s and early 2000 s has done nothing to resolve these grievances. To the contrary, it has added new ones to them. The recent actions and attitudes by French politicians like Brigitte Girardin, Christian Estrosi, and Nicolas Sarkozy toward French Polynesia, arbitrarily modifying the rules of local politics and meddling therein 
in order to keep or put their favorites in power, or simply attempting to declare independence "banned," have further contributed to the impression that French Polynesia is still under colonial rule. In other words, yes, in a metaphorical sense, Angelo Neuffer's 1999 song is correct, and France has indeed continued to behave "mai te hau Roma ra te huru." However, as his song reminds us, not only are Caesar's descendants still alive but also Herod's. In every stage of French colonial policy, Tahitians have collaborated with the French colonial regime and thereby enabled the effectiveness of its policies on the ground.

For all these reasons, the campaign started by President Temaru to reinscribe French Polynesia as a NSGT has been a logical and reasonable undertaking. As explored earlier in detail, the long absence of French Polynesia from that list represented a great anomaly, since virtually all other dependent territories in the Pacific and the Caribbean (including most European Union-affiliated overseas countries and territories) have been listed therein. ${ }^{33}$ As Carlyle Corbin, an international law scholar who specializes in decolonization, commented, "This kind of premature removal of territories from the UN list is known well by advocates and scholars in Puerto Rico, by the ... president of French Polynesia and by political leaders in other territories who have argued that their territories should be re-listed according to contemporary standards of international self-government" $(2009,4)$. The continuation of that anomaly represented, in addition to the memories of the Pouvanaa trial and the effects of nuclear testing, one of the manifestations of the unresolved colonial trauma.

The hostile attitude of the French government to the campaign for reinscription- evidenced recently in the personal intervention made by French Foreign Minister Alain Juppé during the 20 I I Pacific Forum meeting in order to lobby Pacific leaders into watering down the meeting's resolution on the matter (TP, 6 Sept, Io Sept 20II) - only serves to deepen the impression that France continues to behave as a colonizer. As for the local pro-French leaders, it is difficult to understand what they fear from the territory's reinscription as a NSGT. A lone voice of reason in that sense was Representative Eléanor Parker, who, during the I 8 August 20I I debate on the reinscription resolution in the Assembly of French Polynesia made a brilliant speech, identifying herself as an opponent of independence but arguing that only a decolonization process under UN oversight could guarantee a reasonable debate on the topic and a fair vote of self-determination, without fear of manipulation by the French government (TP, I 8 Aug 2OII). The only rational motivation for those ferociously opposed to 
reinscription might be the fact that almost all of them had been members and associates of the corrupt and authoritarian Flosse government before 2004, and one could assume their concern about the country being too closely audited and examined by a neutral outside body such as the UN decolonization committee.

As Jean-Marc Regnault has repeatedly remarked, this situation contrasts markedly with that of New Caledonia, reinscribed as a NSGT for more than twenty years, where today no one in the political spectrum objects to the territory's decolonization, even though the pro-French parties there want the process of decolonization to result in a status other than independence (Regnault 20IIb). With the political system of that territory, deriving from the Noumea Accord, as an alternative concept of autonomy within the French system in view, Oscar Temaru and other pro-independence leaders of French Polynesia (including Flosse during his alliance with Temaru in 2007-2009) have thus for some time proposed to use the idea of the Noumea Accord as a model and have requested that a similar "Tahiti Nui Accord" be enacted for French Polynesia (TP, 24 June 2005; TPM, April 2006; NT, 2I July 2007; Al Wardi and Regnault 20II, I03). This would notably include an acknowledgment by the French government of the trauma caused by colonization as an important step toward reconciliation (Al Wardi 2008, 237). But like all other constructive suggestions for a dialogue to decolonize the country, this idea has not found any resonance with the French government so far.

As related earlier, it must be underlined once more that decolonization means self-determination, not necessarily independence. Besides integration (which in the French case would mean départementalisation), the third option under the UN decolonization regime, free association, could offer some interesting new possibilities. Resolution I 54I (XV) of I960 defines free association as a "result of a free and voluntary choice of the peoples of the territory" and underlines that it should respect "the individuality and the cultural characteristics of the territory and its peoples" (UN I960b, annex, principle VII [a]). Most importantly, free association must provide for the people of the territory the "freedom to modify the status of that territory through the expression of their will," which implies the right of the territory to unilaterally end the relationship of free association with the metropolitan country and become fully independent (Igarashi 2002, 242-246). Free association thus implies the right to sovereignty and is thereby clearly distinguished from any forms of territorial autonomy in which the ruling state retains sovereignty. The Cook 
Islands, neighboring and closely connected culturally and genealogically to French Polynesia, as a self-governing state in free association with its former colonial ruler New Zealand, might be an interesting model in that sense. ${ }^{34}$ According to Regnault (2007, IOI-IO2), directly following the Cook Islands model would be impossible under the French constitution, but once French Polynesia is independent, an association agreement between the two countries could be possible (Government of France I958, article 88). On the other hand, if the constitutional articles relating to the Communauté Française, deleted in 1995 as related above, were restored, an arrangement of full self-government short of complete independence that would indeed be quite similar to that of the Cook Islands might be possible as well.

In any case, it is clear that presenting the current statute of autonomy with all its flaws as a form of decolonization constitutes nothing less than "intellectual fraud," as Senator Tuheiava has stated recently (Massau 20II, 2I). A sincere, unconstrained dialogue on a new institutional framework, including a revisiting of past injustices and the involvement of neutral international institutions such as the United Nations, is certainly overdue. This is warranted not only by the continuing injustices within French Polynesia; a rectification of the current anomalous political status of the territory through reinscription as a NSGT would also reinforce the validity and strength of the principles of international law and thereby contribute to the promotion of world peace, security, stability, and international cooperation.

On 6 May 20I 2, François Hollande of the Socialist Party won the French presidential election and succeeded Nicolas Sarkozy in office. This change in power in Paris represents the possibility of great change in the relation between France and French Polynesia. For many years, the Socialist Party has had an official partnership agreement with Oscar Temaru's Tavini Huiraatira party, and unlike the hostile attitudes shown by the right-wing leaders of the UMP, the relationship between Temaru and Socialist leaders has been cordial in the recent past. The Socialist victory in France thus opens the possibility for a different attitude of France vis-à-vis Tahiti. In the past, French Socialist politicians have shown to be more willing to enter into constructive dialogue with colonized peoples, for instance, during the civil war-like troubles in New Caledonia in the I980s, followed by Michel Rocard's initiative to conclude the 1988 Matignon Accord and Lionel Jospin's engagement with the I998 Noumea Accord. After all, it was also the Socialists who passed the extended statute of autonomy for 
French Polynesia in 1984. On the other hand, however, one must also not forget that Socialist President François Mitterrand (in office I98I-I995), of all French presidents, was the one who ordered the largest number of nuclear tests and that it was the same Socialist government that perpetrated not only the assassination by snipers of Kanak leader Eloi Machoro in 1985 (Robie 1989, I16-I26) but also the only documented case of state-sponsored terrorism by a Western, supposedly democratic, government when French secret agents set up a bomb to sink the Greenpeace ship Rainbow Warrior in Auckland Harbour the same year (Robie I989, I77-I95). But with new generations of progressive political leaders rising, there is hope that these colonial crimes of the Socialists will one day be admitted and apologized for, just like those of de Gaulle. What Hollande has already made clear is that he fully respects the stipulations of the Noumea Accord and recognizes the right of New Caledonia to selfdetermination (Outre-Mer Première 20I2). If by the end of this decade the Noumea process will indeed lead to either independence or a form of free association for that territory, it remains to be seen whether it will have a domino effect on French Polynesia.

I WOULD LiKe to THANK Terence Wesley-Smith and Jan Rensel as well as the four anonymous reviewers. Their critical and helpful comments and ideas helped to organize bits and pieces drawn from my master's thesis into a more coherent article. All translations from the French and Tahitian are by the author except as noted.

\section{Notes}

I Spelled Maohi, Ma'ohi, Mā'ohi, or Māòhi according to various orthographic systems in use, Maohi is the Tahitian word for the native Polynesian people. Since French Polynesia is obviously a colonial name, reminiscent of British West Africa, French Indochina, and the like, various proposals have been made for an indigenous name for the country, among them Tahiti Nui (Greater Tahiti); Fenua Maohi (Maohi Country); Te Ao Maohi (The Maohi World); and Maohi Nui (Greater Maohi), with the latter being currently favored by Oscar Temaru. Since none of the several phonetic spelling systems is currently universally recognized, I here spell all Tahitian words without any diacritics.

2 Editor Alex du Prel of Tahiti Pacifique Magazine. Literally, du Prel decried President Oscar Temaru's insistence on “inscription à l'oNu et autres incessantes 
attaques paranoïaques contre l'Etat" and declared the loi-cadre to be a "loi vite abolie à Tahiti par le référendum de I958" (TPM, Feb 2008, 5, 7).

3 Neuffer 1999. Where the meaning of a Tahitian word or expression is ambiguous, the French translation provided in the $\mathrm{CD}$ liner notes has been used as a guideline.

4 "La Polynésie ne se donna pas à la France, elle dût être conquise par les armes" (Toullelan I99I, I8).

5 All French laws and decrees cited are taken from Lechat I990 unless otherwise indicated.

6 When Pouvanaa was finally allowed to return to the territory in I968, he was a broken old man and no longer able to lead a strong political movement, even though he was highly revered and in I97 I was elected senator, a position he held until his death in 1977 . See Regnault I996, 205.

7 The pamphlet stated, "La police est trop complaisante à leur égard. . . . Il faut les chasser ou les abattre [The police are too nice to them (Pouvanaa and his followers). . . . They need to be chased out or eliminated)]." Quoted in Regnault I996, I03, I79 and Saura I997, 359.

8 Other local politicians, however, collaborated with the French authorities, leading to a vote in the permanent committee of the territorial assembly to grant the French government title to the atolls of Moruroa and Fangataufa free of charge in I964 (Danielsson and Danielsson I993, I27; Regnault I996, I95).

9 Regnault, in collaboration with Catherine Vannier, recently published a definitive summary of all previous research on the Pouvanaa case in order to facilitate his judicial rehabilitation (Regnault and Vannier 2009).

Io "Il doit être bien entendu que la Polynésie française doit demander le statut de territoire d'outre-mer et non celui de membre de la Communauté" (quoted in Regnault 2003b, 2I). See also Regnault 2006, 2 I 7.

I I Earlier, in I982, followers of Pouvanaa had erected a monument in his honor in front of the Assembly building, where it still stands today (Saura I997, 44 I-443). Not replacing a French monument, and not directly criticizing French government policies, it appears to have been accepted more easily by the colonial administration than Temaru's measures in 2006.

I 2 Contemporary observers Virginia Thompson and Richard Adloff noted the political status of the French Pacific territories in the I96os to be "not only anomalous but also anachronistic, in view of the rapidity with which many other Pacific islands with far smaller resources and European populations are moving towards autonomy" (I97I, 4).

I3 "Fidèle à sa mission traditionnelle, la France entend conduire les peuples dont elle a pris la charge à la liberté de s'administrer eux-mêmes et de gérer démocratiquement leurs propres affaires; écartant tout système de colonisation fondé sur l'arbitraire, elle garantit à tous l'égal accès aux fonctions publiques et l'exercice individuel ou collectif des droits et libertés proclamés ou confirmés ci-dessus.” 
I4 Saint-Pierre and Miquelon does not have any aboriginal population, its inhabitants being entirely of French metropolitan origin. The argument of a non-applicability of article $73 \mathrm{e}$ thus makes sense in regard to this territory. As for the French Establishments in India, this latter territory was subsequently annexed by the Republic of India in the I950s, thereafter ceasing to be a matter of French decolonization. Therefore, of the four French overseas territories removed in I947, the EFO and New Caledonia cases should be of most concern here.

I 5 Before the recent campaign by President Temaru, measures to initiate a reinscription process for French Polynesia were taken by the Solomon Islands government in I990 (Henningham I992, 200) and by the Papua New Guinea government in I996 (Maclellan and Chesnaux I998, 247-248), both apparently with no follow-up. The reason for this apparent inconsistency in Pacific Islands foreign policy_-giving full support to New Caledonia's reinscription while withholding the same for French Polynesia-might be the absence of intercommunal violence and large-scale settler colonialism in Tahiti, both of which were and are present in New Caledonia (Mrgudovic 2008, 392-393).

I 6 The subsequent transfer of sovereignty to Guinea happened in a bitter breakup of all relations with France, whose officials committed acts of sabotage as a sort of revenge when they were leaving (Betts I99I, I25).

I 7 In the case of the Comoros, however, France has retained control to this day over one of the islands, Mayotte, while the Republic of the Comoros, supported by the African Union and the majority of UN member states, upholds its claim to the island and sees France's control of Mayotte as a violation of Comorian sovereignty (Caminade 2003).

I 8 Renaud Meltz has pointed out the paradox that de Gaulle decolonized most of the French empire while reaffirming French imperialism in the Pacific (20IO).

I9 For a discussion of the role of the Pacific territories in French geostrategic interests, see Aldrich I993, 336, 352; Maclellan and Chesnaux I998, 82-88.

20 See entries for the named territories on the World Statesmen website (http://worldstatesmen.org, accessed 27 April 2008), which show a period with elected local chief executives before independence for each of them. For an overview of the successful decolonization processes of Pacific Island territories, including transitional periods of territorial autonomy, see also Naidu I993.

2 I For a critical analysis of Gaston Flosse's governance during the late I990s and early 2000s, see Regnault 2004, 97-II9.

22 Compare, for instance, the headline "Un statut pour réussir" (A Statute for Success) in the pro-Flosse weekly Ti'ama (27 Feb 2004) with the headline "Menaces sur la démocratie" (Threats to Democracy) in the opposition weekly To'ere ( I 8 Dec 2003). For a critical analysis of the 2004 statute, see also Regnault 2007, 90-97.

23 For detailed descriptions and analyses of these repeated changes in govern- 
ment, see David Chappell's and my own annual reviews of French Polynesia in The Contemporary Pacific (Chappell 2005; Gonschor 2006, 2007, 2008, 2009, 20IO, 2OII, 20I2).

24 L'accord de Noumea, 5 May I998, reprinted in Faberon and Postic 2004, I4-24.

25 Despite these provisions, New Caledonia has more recently experienced a high degree of executive instability as well (see Chappell 20I2).

26 For the relevant legal texts and a brief comment on the New Caledonia case, see Faberon and Postic 2004. For a more extensive discussion of the Noumea Accord and its ramifications, see Chappell I999.

27 The British possessions of Bermuda and Gibraltar, for instance, both on the NSGT list, have autonomous territorial governments, responsible for almost all matters in Bermuda and all matters except foreign affairs, internal security, and defense in Gibraltar. See Government of Bermuda 20I I and Government of the United Kingdom 2006.

28 According to testimonies in the pro-independence weekly To'ere (24 July 2003 ), activists were subjected to torture-like abuses during arrests following violent protests against the resumption of nuclear testing in September 1995.

29 This quotation is from an RFO television report on 23 May 2004. RFO (Réseau France Outre-mer) is the former name of a network of television stations operating in French overseas departments and collectivities around the world. The network is now called Outre-mer Première.

30 In the original French: "Le processus électoral est loin d'être terminé."

3 I For the details of these tumultuous events and the partisan attitude of the French government, see Regnault 2004, I2I-I74; Saura 2004; Guiselin 2005; and, from a pro-Flosse point of view, Haupert 2005.

32 In the original French: "pratiques coloniales en faveur d'un clan."

33 This anomaly became dramatically manifest in May 20I0 when a French Polynesian delegation led by Oscar Temaru attempted to attend the annual Regional Seminar of the UN Decolonization Committee in Noumea, New Caledonia, at the invitation of Kanak independence leaders but was denied entry and physically removed from the scene by French police forces, on the grounds that French Polynesia is not on the list of NSGTs (TPM, June 20I0).

34 For a discussion of the Cook Islands and other freely associated states in the Pacific (Niue, the Federated States of Micronesia, the Marshall Islands, and Palau), see Henderson 2002.

\section{References}

Ahmad, S Hasan

I974 The United Nations and the Colonies. New York: Aligarh Muslim University and Asia Publishing House. 
Aldrich, Robert

I993 France and the South Pacific since I940. Honolulu: University of Hawai'i Press.

Al Wardi, Sémir

2008 Tahiti Nui ou les dérives de l'autonomie. Series Portes Océanes 5. Paris: L'Harmattan.

Al Wardi, Sémir, and Jean-Marc Regnault

20I I Tahiti en crise durable: Un lourd héritage. Moorea: Les Éditions de Tahiti.

APF, Assemblée de la Polynésie française

2006 Les polynésiens et les essais nucléaires: Indépendance nationale et dépendance polynésienne. Comité d'enquête sur les conséquences des essais nucléaires. Délibération No 2005-072/APF du I5 juillet 2005, JOPF du 28 juillet 2005. Papeete: APF.

Barillot, Bruno

2002 L'héritage de la bombe: Sahara, Polynésie (1960-2002): Les faits, les personnels, les populations. Lyon: Centre de documentation et de recherche sur la paix et les conflits.

Betts, Raymond F

I99I France and Decolonization I900-1960. New York: St Martin's Press.

Caminade, Pierre

2003 Comores-Mayotte: Une histoire néocoloniale. Dossiers noirs I9. Marseille: Agone.

Céran-Jérusalémy, Jean-Baptiste Heitarauri Tautu

200I Des souvenirs de I92 I à nos jours. Papeete: published by author.

Chappell, David A

I999 The Noumea Accord: Decolonization Without Independence in New Caledonia? Pacific Affairs 72 (3): 373-391.

2005 French Polynesia. Polynesia in Review: Issues and Events, I July 2003 to 30 June 2004. The Contemporary Pacific I7:193-203.

20I2 New Caledonia. Melanesia in Review: Issues and Events 20II. The Contemporary Pacific 24:389-398.

Corbin, Carlyle

2009 Caribbean Self Determination in the 2 ist Century. Address to a conference of Pueblo Soberano of Curaçao, Netherlands Antilles, 27 November. Published online in the Overseas Territories Report 8 (4): I-IO. http://www.normangirvan.info/wp-content/uploads/2009/I 2/ corbin-caribbean-self-determination.pdf [accessed ro Sept 2010]

Danielsson, Bengt, and Marie-Thérèse Danielsson I986 Poisoned Reign: French Nuclear Colonialism in the Pacific. Second 
revised edition. Ringwood, Australia: Penguin Books. Originally published in 1977 .

I993 Moruroa, notre bombe coloniale: Histoire de la colonisation nucléaire de la Polynésie française. Paris: L'Harmattan.

de Vries, Pieter, and Han Seur

I997 Moruroa and Us: Polynesians' Experiences during Thirty Years of Nuclear Testing in the French Pacific. Lyon: Centre de documentation et de recherche sur la paix et les conflits.

Dorrance, John C

I966 The Pouvanaa Movement and Political Development in Post-War French Polynesia. Research paper, University of Hawai'i. Copy in UH Hamilton Library.

DT, La Depêche de Tahiti. Daily newspaper. Tahiti.

El-Ayouty, Yassin

I97 I The United Nations and Decolonization: The Role of Afro-Asia. The Hague: Martinus Nijhoff.

Faberon, Jean-Yves, and Jean-Raymond Postic, editors

2004 L'accord de Noumea, la loi organique et autres documents juridiques et politiques de la Nouvelle-Calédonie. Noumea: Éditions Île de Lumière.

Fiji Ministry of Information

2012 Non-Aligned Movement (NAM) Members agree to Fiji and PNG Proposal. I4 May. Posted on Fiji Government website: http://www.fiji .gov.fj/index.php?option=com_content $\&$ view=article\&id=6I 4 I :non -aligned-movement-nam-members-agree-to-fiji-and-png-proposal \&catid=7I:press-releases\&Itemid=I 55 [accessed 26 Feb 20I3]

Flosse, Gaston

2009 Gaston Flosse a voté au Sénat pour l'adoption de la loi Morin. Le blog de Gaston Flosse. http://gastonflosse.typepad.fr/mon_weblog/2009/ Io/-gaston-flosse-a-vot $\% \mathrm{C}_{3} \% \mathrm{~A}_{9}$-au-s $\% \mathrm{C}_{3} \%$ A 9 nat-pour-ladoption -de-la-loi-morin.html [accessed I 4 June 20I 2]

Fry, Greg

I997 The South Pacific "Experiment": Reflections on the Origins of Gille, Bernard

Regional Identity. The Journal of Pacific History 32 (2): 180-202.

2006 Histoire des institutions politiques à Tahiti du XVIIe siècle à nos jours. Papeete: Ministère de l'Education, Centre de recherche et de documentation pédagogique de la Polynésie française.

Gonschor, Lorenz

2006 French Polynesia. Polynesia in Review: Issues and Events, I July 2004 to 30 June 2005. The Contemporary Pacific I8:I33-I43. 
2007 French Polynesia. Polynesia in Review: Issues and Events, I July 2005 to 30 June 2006. The Contemporary Pacific I9:2I3-222.

2008 French Polynesia. Polynesia in Review: Issues and Events, I July 2006 to 30 June 2007. The Contemporary Pacific 20:222-23 I.

2009 French Polynesia. Polynesia in Review: Issues and Events, I July 2007 to 30 June 2008. The Contemporary Pacific 2I:I 5 I-I 62.

2010 French Polynesia. Polynesia in Review: Issues and Events, I July 2008 to 30 June 2009. The Contemporary Pacific 22:I68-I79.

20I I French Polynesia. Polynesia in Review: Issues and Events, I July 2009 to 30 June 2010. The Contemporary Pacific 23:2 I 5-227.

2012 French Polynesia. Polynesia in Review: Issues and Events, I July $20 \mathrm{IO}$ to 30 June 20I I. The Contemporary Pacific 24:I72-I 84 .

Government of Bermuda

20I I Government of Bermuda Organizational Chart. http:/www.gov.bm/ portal/server.pt/gateway/PTARGS_o_2_6895_897_232435_43/http $\%_{3} \mathrm{~B} /$ ptpublisher.gov.bm $\%{ }_{3} \mathrm{~B}_{70} 87 /$ publishedcontent/publish/gov top_level__org__house_/gov_org/organisational_chart 2/I 20 I 23 _gov_org_chart.pdf [accessed I 5 June 20I2].

Government of France

I946 La Constitution du 27 octobre I946. Reproduced on the French Constitutional Council website: http://www.conseil-constitutionnel.fr/ conseil-constitutionnel/francais/la-constitution/les-constitutions-de -la-france/constitution-de-I946-ive-republique.5 I09.html [accessed 25 Feb 20I3]

I958 Constitution du 4 octobre I958. Reproduced on the University of Perpignan website: http://mjp.univ-perp.fr/france/cor958-o.htm [accessed I I Jan 2008].

I995 Loi constitutionnelle $n^{\circ} 95-880$ du 4 août I995 portant extension du champ d'application du référendum, instituant une session parlementaire unique, modifiant le régime de l'inviolabilité parlementaire et abrogeant les dispositions relatives à la Communauté et les dispositions transitoires. Posted on University of Perpignan website: http:// mjp.univ-perp.fr/france/coI958-9.htm [accessed I 5 June 20I2].

2003 Loi constitutionnelle $\mathrm{n}^{\circ} 2003-276 \mathrm{du} 28$ mars 2003 relative à l'organisation décentralisée de la République. Posted on University of Perpignan website: http://mjp.univ-perp.fr/france/cor 958-I7.htm [accessed I I Jan 2008].

2004 Statut d'autonomie de la Polynésie française. Papeete: Secrétariat Général du Gouvernement/Imprimerie Officielle de la Polynésie française.

2007 Loi organique $\mathrm{n}^{\circ}$ 2007-I7 I9 du 7 décembre 2007 tendant à renforcer la stabilité des institutions et la transparence de la vie politique en 
Polynésie française. Posted on Legifrance website: http://legifrance .gouv.fr/jopdf/common/jo_pdf.jsp?numJO=o\&dateJO=2007 I 208 \&numTexte $=\mathrm{I} \&$ pageDebut $=\mathrm{I} 9890$ \&pageFin $=\mathrm{I} 9902$ [accessed 20 April 2008].

Government of the United Kingdom

2006 The Gibraltar Constitution Order 2006. http://www.parliament.gi/ images/constitution2006.pdf [accessed I 5 June 20I2].

Guiselin, Emmanuel-Pie

2005 Du premier au second gouvernement Temaru: Une année de crise politique et institutionnelle. Yearbook of the New Zealand Association for Comparative Law 2:1-24.

Haupert, Yves

I998 Francis Sanford à cour ouvert: Les mémoires du dernier metua, père de l'autonomie polynésienne. Papeete: Au Vent des Îles.

2005 Taui: L'espoir trahi. Papeete: Société Polynésienne d'Édition.

Henderson, John

2002 The Politics of Association: A Comparative Analysis of New Zealand and the United States Approaches to Free Association with Pacific Islands States. Special issue, Revue Juridique Polynesienne 2:77-86.

Henningham, Stephen

I992 France and the South Pacific: A Contemporary History. South Sea Books. Honolulu: Center for Pacific Islands Studies and University of Hawai'i Press.

Ibrahime, Mahmoud

2000 La naissance de l'élite politique comorienne (1945-1975). Series Archipel des Comores. Paris: L'Harmattan.

Igarashi, Masahiro

2002 Associated Statehood in International Law. Series International Law in Japanese Perspective, volume 7. The Hague: Kluwer Law International

Ilari, Noël

I965 Secrets tahitiens: Journal d'un popaa farani. Paris: Nouvelles Éditions Debresse.

Lâm, Maivân Clech

2000 At the Edge of the State: Indigenous Peoples and Self-Determination. Ardsley, NY: Transnational Publishers, Inc.

Lechat, Philippe

I990 Institutions politiques et administratives. Royaume de Tahiti et Dépendances, Etablissements Français de l'Océanie, Polynésie Française. Textes et documents I8I9-I988. Papeete: Assemblée Territoriale. 
Lenormand, Maurice

I99I Décolonisation ratée-Indépendance avortée. Journal de la Société des Océanistes 92-93 (I/2): I4 I-I 55.

Maclellan, Nic, and Jean Chesnaux

I998 After Moruroa: France in the South Pacific. Melbourne: Ocean Press.

Massau, Serge

20I I Paroles d'un autochtone: Entretiens avec le sénateur Richard Tuheiava. Papeete: Éditions Haere Po No Tahiti.

Meltz, Renaud

2010 La bombe et l'invention d'une nation tahitienne. In 5000 ans de culture ultramarine pacifique, edited by Serge Dunis, I87-202. Papeete: Éditions Haere Po No Tahiti.

Mrgudovic, Nathalie

2008 La France dans le Pacifique Sud: Les enjeux de la puissance. Paris: L'Harmattan.

Naidu, Vijay

I993 The Path to Independence. In Culture and Contact in the Pacific, edited by Max Quanchi and Ron Adams, I26-I38. Cambridge: Cambridge University Press.

NAM, Non-Aligned Movement

20I2 I6th Summit of Heads of State or Government of the Non-Aligned Movement. Tehran, Islamic Republic of Iran, 26-3 I August. Final Document. Posted on NSNBC blog: http://nsnbc.files.wordpress.com/ 20I 2/o6/finaldocumentnam20 I 2-doc-I-rev-23.pdf [accessed Io Nov 20I 2]

Neuffer, Angelo Ariitai

I999 Atire Atire. Musical album. Papeete: Océane Production.

NT, Les Nouvelles de Tahiti. Daily newspaper. Tahiti.

Outre-Mer Première (French government television network for overseas departments and collectivities)

20I2 Interview with François Hollande, 25 February. Posted on You-

Tube website: http://www.youtube.com/watch?v=vABG-kNBs4 8 [accessed 22 June 20I2]

Pratibha, Jyoti

20 I Fiji, PNG: Let Maohi Nui Say. Fiji Sun, I 3 May. http://www.fijisun .com.fj/2012/05/I3/fiji-png-let-maohi-nui-say/ [accessed 24 Jan 2013]

Regnault, Jean-Marc

I996 Te Metua: L'échec d'un nationalisme tahitien I942-I962. Papeete: Éditions Polymages.

2003a Pouvanaa a Oopa: Victime de la raison d'Etat; Les documents parlent. Moorea: Les Éditions de Tahiti. 
2003 b Affaire Pouvanaa: Les documents continuent à parler ... et les langues à se délier. Tahiti-Pacifique Magazine I49 (September): 2 I-22.

2004 Taui: Oscar Temaru-Gaston Flosse; Le pouvoir confisqué. Moorea: Les Éditions de Tahiti.

2006 La France à l'opposé d'elle-même: Essais d'histoire politique de l'Océanie. Volume I. Moorea: Les Éditions de Tahiti.

2007 Tahiti malade: Malade de ses politiques. Moorea: Les Éditions de Tahiti.

20I Ia Affaire Pouvanaa: Des questions trouvent des réponses. Tahiti Pacifique Magazine 237 (January): 40.

20Irb OnU: Décolonisation et indépendance. Tahiti Pacifique Magazine 240 (April): 38-39.

20IIc Pourquoi les leçons de l'histoire ne sont-ils jamais retenues à Tahiti? Tahiti Pacifique Magazine 243 (August): 36-37.

Regnault, Jean-Marc, and Catherine Vannier

2009 Le metua et le général: Un combat inégal. Moorea: Les Éditions de Tahiti.

Robie, David

I989 Blood on Their Banner: Nationalist Struggles in the South Pacific. London: Zed Books.

Roeder, Philip G

2007 Where Nation-States Come From: Institutional Change in the Age of Nationalism. Princeton: Princeton University Press.

Saura, Bruno

I997 Pouvanaa a Oopa: Père de la culture politique tahitienne. Papeete: Au Vent des îles.

I998 The Emergence of an Ethnic Millenarian Thinking and the Development of Nationalism in Tahiti. Pacific Studies 2 I (4): 33-65.

2004 La société tahitienne au miroir d'Israël: Un peuple en métaphore. Paris: CNRs Éditions.

Tagupa, William

I976 Politics in French Polynesia I945-1975. Wellington: New Zealand Institute of International Affairs.

Thompson, Virginia, and Richard Adloff

I968 Dibouti and the Horn of Africa. Stanford: Stanford University Press.

I97I The French Pacific Islands: French Polynesia and New Caledonia. Berkeley: University of California Press.

Ti'ama. Weekly newspaper. Tahiti, 2004.

To'ere. Weekly newspaper. Tahiti, 200I-2006.

Toullelan, Pierre-Yves

I99 Comment la Polynésie et devenue française . . . / Mea nafea to Porinetia riroraa mai ia Farani. Printed bilingual document. Part of 1992 
instructional packet of the political party Tavini Huiraatira No Te Ao Maohi. Translated into Tahitian by James Salmon. Copy in the author's possession.

Toullelan, Pierre-Yves, and Bernard Gille

I994 Le mariage Franco-Tahitien: Histoire de Tahiti du XVIIIe siècle à nos jours. Papeete: Éditions Polymages-Scoop.

TP, Tahitipresse. Daily Internet news. Tahiti. http://www.tahitipresse.pf

TPM, Tahiti-Pacifique Magazine. Monthly. Tahiti. http://www.tahiti-pacifique.com UN, United Nations

I945 Charter of the United Nations. Posted on the UN website: http:// www.un.org/en/documents/charter/index.shtml [accessed 25 Feb 20I3]

I946 United Nations General Assembly resolution 66 (I). Transmission of information under Article 73e of the Charter. Posted on the UN website: http://www.un.org/ga/search/view_doc.asp?symbol=A/RES/ 66(I)\&Lang=E\&Area=RESOLUTION [accessed 25 Feb 20I3]

I960a United Nations General Assembly Resolution I5I4 (XV). Declaration on the granting of independence to colonial countries and peoples. Posted on the UN website: http:/www.un.org/ga/search/ view_doc.asp? sy mbol=A/RES/I 5 I 4 (XV) \& Lang=E \&Area =RESOLUTION [accessed 25 Feb 20I3]

I960b United Nations General Assembly Resolution I 54 I (XV). Principles which should guide Members in determining whether or not an obligation exists to transmit the information called for under article $73 \mathrm{e}$ of the Charter. Posted on the UN website: http://www.un .org/ga/search/view_doc.asp?symbol=A/RES/I 54 I XV)\&Lang=E \&Area=RESOLUTION [accessed 25 Feb 20I3]

I966 United Nations General Assembly Resolution 2228 (XXI). Question of French Somaliland. Posted on UN website: http://www.un.org/ga/ search/view_doc.asp?symbol=A/RES/2228(XXI)\&Lang=E\&Area =RESOLUTION [accessed 25 Feb 20I3]

I973 United Nations General Assembly Resolution 3 I6I (XXVIII). Question of the Comoro Archipelago. Posted on UN website: http:// daccessdds.un.org/doc/RESOLUTION/GEN/NRo/282/33/IMG/ NRo2 8233.pdf? OpenElement [accessed 22 Jan 2008]

I986 United Nations General Assembly Resolution 4I/4I. Implementation of the Declaration on the Granting of Independence to Colonial Countries and Peoples. Posted on UN website: http://www.un.org/ ga/search/view_doc.asp? symbol=A/RES/4 I/4 I \&Lang=E\&Area $=$ RESOLUTION [accessed 25 Feb 20I3]

20I3 United Nations General Assembly, sixty-seventh session, agenda item 60. A/67/L.56/Rev.I. Implementation of the Declaration on 
the Granting of Independence to Colonial Countries and Peoples. Nauru, Solomon Islands and Tuvalu draft resolution: Self-determination of French Polynesia. Passed as Resolution 67/265 on I 7 May 20I3. Posted on UN website: http://www.un.org/ga/search/view_doc Yacono, Xavier .asp?symbol=A/67/L.56/Rev.I [accessed I 8 May 20I3]

I97I Les étapes de la décolonisation française. Series Que sais-je, $\mathrm{n}^{\circ} 428$. Paris: Presses Universitaires de France.

\begin{abstract}
From a French perspective, French Polynesia is often described as an overseas territory that has been virtually decolonized through the granting of statutes of autonomy. In stark contrast, pro-independence local political parties still consider the country a colony and have successfully lobbied for a process of decolonization under United Nations oversight. This article assesses these competing claims through an analysis of the political evolution of the territory since World War II. The analysis shows that French Polynesia has never been genuinely decolonized. In the I940s, I950s, and I960s, the French government arbitrarily pulled the territory out of all available international or French domestic decolonization processes, subjecting it to an anachronistic restoration of colonial authority that included the arrest and long-term imprisonment of its major political leader and a series of other unusually undemocratic measures. This led to, and culminated in, the construction of a nuclear testing facility, with tremendous environmental, health, and economic consequences during the following three decades. Later, after giving in to local protests demanding autonomy, France misused that concept not only to cover up a de-facto continuity of colonial rule but also to create a corrupt authoritarian local government favorable to French interests. Recent actions taken and attitudes demonstrated by the French government and its representatives, including repeated arbitrary modifications of the rules of local politics and meddling therein in order to secure their favorites in power, have shown that French colonialism in French Polynesia is alive and well. An international campaign for the decolonization of the country is thus clearly warranted.
\end{abstract}

KEYWORds: Tahiti, French Polynesia, colonialism, neocolonialism, autonomy, decolonization, self-determination. 